\title{
Toplumsal Cinsiyet Perspektifinden Erkek Sosyal Hizmet Uzmanlarının Sosyal Hizmet Mesleğine Yönelik Deneyimleri
}

\author{
Experiences of Male Social Workers from the Gender Perspective in the \\ Profession of Social Work
}

\section{Sinan AKÇAY * Eda BEYDİLİ GÜRBÜZ **}

$\ddot{\boldsymbol{O}}_{\boldsymbol{z}}$ : $\mathrm{Bu}$ araştırma toplumsal cinsiyetin erkek sosyal hizmet uzmanlarının mesleki yaşamlarına nasıl yansıdığını keşfetmek amacıyla yapılmıştır. Fenomenolojik yaklaşımın kullanıldığı araştırmada 25 sosyal hizmet uzmanına ulaşılmıştır. Çalışmada açık uçlu anket formu kullanılmıştır. Nitel veri analiz programı olan MAXQDA kullanılarak yapılan analiz sonucunda sosyal hizmet uzmanlarının erkeklik algıları, sosyal hizmetin kadınlara özgü bir meslek olup olmadığına ilişkin algıları ve sosyal hizmet uygulamalarında erkek sosyal hizmet uzmanı olmak temalarına ulaşılmıştır. Araştırma sonucunda erkek sosyal hizmet uzmanlarının toplumsal cinsiyet rolünü benimsemediği, sosyal hizmeti kadınlara özgü bir meslek olarak görmediği ve sosyal hizmet uygulamaları sırasında erkek sosyal hizmet uzmanı olarak otorite olarak görülmeleri, uygulamalar sırasında karşılaştıkları tehlikeli durumların üstesinden gelmeleri, kadın müracaatçılar ile iletişim kuramamaları gibi noktalarda çeşitli avantaj ve dezavantajlara sahip olduğu görülmüştür. Çalışmada erkek sosyal hizmet uzmanlarının toplumsal cinsiyete duyarlı olmasının önemi vurgulanmaktadır. Çalışma, toplumsal cinsiyetin sosyal hizmet uygulamalarındaki yansımalarını sosyal hizmet uzmanlarının deneyimleri üzerinden keşfetmesi nedeniyle hem eleştirel erkeklik çalışmaları hem de sosyal hizmet disiplini açısından alana katkı sağlamaktadır.

Anahtar sözcükler: Sosyal Hizmet, Erkek Sosyal Hizmet Uzman1, Erkeklik, Toplumsal Cinsiyet

\begin{abstract}
This study was conducted to explore how gender is reflected in the professional lives of male social workers. 25 social workers were reached in this study, which used the phenomenological approach. An open-ended questionnaire was used. As a result of the analysis conducted using MAXQDA, a qualitative data analysis program, the perception of the masculinity of social workers, perceptions of whether social work is a profession specific to women, and the themes of being a male social worker in social work practices were investigated. As a result of this research, it was found that male social workers do not adopt the traditional masculinity role, do not see social work as a profession specific to women, and have various advantages and disadvantages in terms of being seen as an authority as a male social worker during social work practices, overcoming the dangerous situations encountered during their work, and not being able to communicate with female clients, as male social workers during social work practices. In this study, it is emphasized that male social workers should be gender sensitive. The study contributes to the field, both in terms of critical masculinity studies and social work discipline as it explores the reflections of gender on social work practices through the experiences of social workers.
\end{abstract}

Keywords: Social Work, Male Social Worker, Masculinity, Gender

* Dr. Öğr. Üyesi., Selçuk Üniversitesi Sağlık Bilimleri Fakültesi, Sosyal Hizmet Bölmü, Konya. sinan.akcay@selcuk.edu.tr, https://orcid.org/0000-0001-9485-5891

** Dr. Öğr. Üyesi., Düzce Üniversitesi Sağlık Bilimleri Fakültesi, Sosyal Hizmet Bölümü, Düzce. edagurbuz@duzce.edu.tr, https://orcid.org/0000-0003-1680-5439 
İstihdam alanları ile cinsiyet arasındaki ilişki tarihsel olarak tartışılagelmiştir. Öğretmenlik, mühendislik gibi bazı mesleklerin istihdam alanları erkeklere ya da kadınlara özgü faaliyetler olarak görülme eğilimi taşımaktadır. Sosyal hizmet mesleği de cinsiyete özgü istihdam alanları tartışmalarının yoğun olarak yapıldığı mesleklerden biridir.

İnsan hakları ve sosyal adaleti sağlamayı amaç edinen bir disiplin olan sosyal hizmet 1800'lü yıllarda sanayileşmenin etkisiyle ortaya çıkan sosyal sorunları ortadan kaldırmak ve özellikle kentlerde yaşayan yoksul insanların gereksinimlerini karşılamak amacıyla ortaya çıkmıştır. Başlangıçta yoksul, engelli, yaşlı, çocuk vb. dezavantajlı grupların ihtiyaçlarını karşılamak amacıyla gönüllülük ve hayırseverlik ekseninde başlayan yardımlar zaman içinde daha sistematik bir şekilde yapılmaya başlanmış ve ihtiyaçların giderilmesinin bir hak olduğu gerçeğinin anlaşılmasıyla bir disiplin içerisinde yapılması gerektiği kabul edilmiştir (Zastrow 2013) Sosyal hizmetin henüz hayırseverlik anlayışla yapılmaya başladığı dönemlerde kadınların etkisi büyük olmuştur (Chambers 1986). Chicago'da Hull House'u kurarak yoksulların ihtiyaçlarını karşılayıp yaşamsal becerilerini arttırmaya yönelik çalışmaların öncüsü olan Jane Addams (Knight 2014) ve sosyal hizmetin kuram ve yöntem çerçevesinde yapılmasını öneren Sosyal Teşhis (Social Diagnosis) kitabının yazarı Mary Richmond (Zastrow 2013) gibi, müracaatçıları bulundukları ortamda ziyaret eden, hayırsever derneklerinde gönüllü çalışanlar çoğunlukla kadınlar olmuştur. Kuşkusuz kadınların böylesi bir mesleğin öncüleri olmasında "kadının duygularıyla hareket ettiği ve temel görevinin bakım verme olduğunu" öne süren ve bugün de sosyal bilimlerce tartışılan toplumsal cinsiyet meselesinin derin izleri vardır.

Sosyal hizmet erkekler için geleneksel olmayan mesleklerden biri olarak görülmektedir. $\mathrm{Bu}$ durum sosyal hizmetin "bakım" mesleği olarak görülmesi ile ilgilidir. Sosyal hizmet kontrol ve gözetimi içeren çalışmaları içerse de, bakım vurgusunun fazla olması sosyal hizmetin feminen bir meslek olarak konumlanmasına neden olmaktadır. Diğer bir yandan sosyal hizmet uzmanlarının büyük bir çoğunluğunu kadınlar oluştururken; müracaatçıların büyük bir çoğunluğunu da doğrudan ya da dolaylı olarak kadınlar oluşturmaktadır (Hanmer \& Statham 1999 akt. Hicks 2015; Orme 2009 akt. Teater 2015). Dolayısıyla erkekler hem sosyal hizmet uygulamasinda hem de sosyal hizmetlerin kullanımında azınlıkta olma eğilimi taşımaktadır (Christie 2001). Sosyal hizmet öğrencilerinin cinsiyete göre dağılımına bakıldığında da kadın öğrencilerin ağırlıkta olduğu görülmektedir. Örneğin Yükseköğretim Program Atlası'nın 2018 yılı verilerine göre Selçuk Üniversitesi Sosyal Hizmet Bölümü’ne kayıtlı öğrencilerin \%71,7’ü kadın, \%28'i erkektir. Benzer bir şekilde uzun yıllar cinsiyete dayalı kota koyarak eşit sayıda öğrenci alan ve sosyal hizmet eğitiminin verilmeye başlandığı ilk yer olan Hacettepe Üniversitesi Sosyal Hizmet Bölümü'ne kayıtlı öğrencilerin \%76,6'sı kadın, \%23,4'ü ise erkektir (https://yokatlas. yok.gov.tr/index.php). Christie (1998) sosyal hizmetin erkekler için geleneksel olmayan mesleklerden biri olabileceğini tartıştığ 1 çalışmasında sosyal hizmet alanında yeterli olmak için cinsiyetçilik karşıtı uygulama, feminist analiz vb. konuları içeren baskı karşıtı uygulama konusunda yetkin olunması gerektiğine dikkat çekmektedir. Diğer bir yandan sosyal hizmet uzmanları müracaatçıların yaşadıkları yerlerde sosyal inceleme yapmakta, sosyal inceleme kapsamında yaşamlarını incelemekte ve onlarla beraber bakım ve kontrole ilişkin kamuoyu gündemini etkilemektedir. Sosyal hizmetin kamusal alan ile özel alan arasındaki bölgede konumlanıor olmas1nın sosyal hizmeti erkekler için geleneksel olmayan meslekler sınıflandırmasına dahil etmenin bir nedeni olarak ifade edilmektedir (Christie 1998).

McPhail (2004), sosyal hizmetin kadınların baskın olduğu meslek olarak tanımlanmasına karşı çıkarak sosyal hizmet mesleğinde kadınların sayı olarak çoğunluğu oluştursa da, mesleğin kontrolüne ilişkin bir baskınlığa sahip olmadığına dikkat çekmektedir. Sosyal hizmet içeriğinin çoğunluğu erkek egemendir, erkekler tarafından geliştirilen ve yönetilen meseleler ön plandadır. $\mathrm{Bu}$ yüzden McPhail sosyal hizmeti kadınların çoğunlukta olduğu ancak erkeklerin baskın oldu- 
ğu bir meslek olarak tanımlamanın daha doğru olacağını vurgulamaktadır. Nitekim sosyal hizmet gibi mesleklerde erkekler daha çok yönetim veya akademi gibi yüksek statüdeki pozisyonları seçmekte veya söz konusu pozisyonlara görevlendirilmektedir (Christie 1998).

Kadınlara özgü olarak nitelendirilen ve kadınların çoğunlukta olduğu mesleklerdeki erkek meslek elemanlarına yönelik literatürde birçok araştırma bulunmaktadır. Literatürde konuyla ilgili yapılan çalışmalara bakıldığında araştırmaların büyük çoğunluğunun hemşirelik (Kaya et al. 2011; Kahraman et al. 2015; Başçı \& Y1lmazel 2016) ve öğretmenlik (Avc1 et al. 2018) alanında yapıldığı görülmektedir. Yağbasan \& Aksoy (2016) tarafından erkek anaokulu öğretmenlerine velilerin bakış açısının incelendiği araştırmada anaokulu öğretmeni denildiğinde öncelikli olarak kadın öğretmenin akla geldiği, velilerin anaokulu öğretmeninin kadın olması gerektiğini düşündüğü, kadın öğretmenin veliler tarafından özellikle tercih edilmesinde kadınlardaki “annelik içgüdüsü”nün baskın olması düşüncesinin etkili olduğu ve erkeklerin kadın öğretmenler kadar öğrencilere ilgi göstereceğine inanılmadığı sonucuna ulaşılmıştır. Toplumun erkek hemşirelere bakışının incelendiği bir araştırmada (Erer, Kanat \& Öğer 2017) ise katılımcıların yarısından fazlasının erkeklerin hemşirelik mesleğini yapması gerektiği, erkeklerin hemşirelik mesleğine olumlu katkılar sağlayacağını düşünürken diğer bir yandan hemşirelik bakımını da hemcinsi olan hemşireden almak istedikleri sonucuna ulaşılmıştır. Erkek hemşireler üzerine yaptığı nitel araştırmada Gönç (2016), erkek hemşirelerin mesleği erilleştirme için hemşireliği eril söylem içinde yeniden tanımlama, duygusal emek gerektirmeyen ve kas gücünün ön planda olduğu alanlarda yoğunlaşma, meslek yerine kariyere odaklanma ve doktor otoritesine itiraz ederek hemşirelik mesleğindeki aile sembolizmini reddetme gibi stratejiler geliştirdiklerini ve bu stratejilerin kadın katılımcılar tarafından da büyük ölçüde desteklendiğini ifade etmektedir. Sosyal hizmet açısından ise yalnızca bir çalışmaya rastlanılmıştır. Açıl (2019), erkek sosyal hizmet uzmanlarının erkeklik algısını incelediği yüksek lisans tezinde "erkek sosyal hizmet uzmanlarının, özellikle mesleki uygulama dışındaki hane içi/dışı özel yaşantılarında 'kısmen' cinsiyetçi yaklaşımlara ve çelişik cinsiyet duygu-durumlarına sahip; hegemonik erkeklik değerlerinin taşıyıcısı durumunda olan bireyler olduklarını" ortaya çıkarmıştır. Bu araştırmada da erkek sosyal hizmet uzmanlarının mesleki yaşamlarına toplumsal cinsiyetin nasıl yansıdığının keşfedilmesi ve literatüre katkı sağlanması amaçlanmaktadır.

\section{Yöntem}

$\mathrm{Bu}$ araştırmada erkek sosyal hizmet uzmanlarının mesleki yaşamlarına toplumsal cinsiyetin nasıl yansıdığını anlama ve keşfetme amacı taşıdığından nitel araştırma yöntemlerinden fenomenolojik desen kullanmıştır. Creswell (2013) göre fenomenolojik çalışma, birkaç kişinin bir fenomen veya kavramla ilgili yaşanmış deneyimlerinin ortak anlamını tanımlar. Fenomenolojik araştırma insanların bazı fenomenleri nasıl tecrübe ettiklerini metodolojik, özenli ve derinlemesine bir şekilde resmedilmesini ve betimlenmesini gerektirir (Patton 2014)

Araştırmada örneklem yöntemlerinden amaçlı örneklem yöntemi kullanılmıştır. Amaçlı örneklemede araştırmaya katılacaklar rastlantısal olmayan bir şekilde zengin bilgi alınabilecek kişilerden seçilir (Neuman 2006; Krysik \& Finn 2015). Bu doğrultuda araştırmaya hali hazırda herhangi bir kurumda çalışan sosyal hizmet uzmanları dahil edilmiş olup veri çeşitliliğini sağlamak amacıyla farklı müracaatçı grupları ile çalışan sosyal hizmet uzmanlarına ulaşılmaya dikkat edilmiştir. Bu kriterleri sağlayan ve araştırmaya katılmayı kabul eden 60 sosyal hizmet uzmanına açık uçlu soruların yer aldığı form e-posta aracılığıyla iletilmiş ve 3 hafta içerisinde yanıt vermeleri beklenmiştir. Katılımcılara birinci ve ikinci haftanın sonunda hatırlatma mailleri gönderilmiştir. Çalışmaya katılmayı kabul eden ancak verilen süre çerçevesinde dönüş yapmayan veya iş yoğunluğunu öne sürerek araştırmaya katılmaktan vazgeçen toplam 31 kişi olmuştur. 4 form ise, deneyim ve algıların yer almaması ya da kısmen yer almasından dolayı araştırma dışında bırakılmıştır. Sonuçta bu araştırma 25 sosyal hizmet uzmanı ile yapılmıştır. 


\section{Katılımcilar}

Araştırma 25 erkek sosyal hizmet uzmanı ile yapılmıştır. Katılımcıların en büyüğü 34, en küçüğü 23 yaşında olup, yaş ortalaması 26,56'dir. Katılımcılar en kısa 5 ay, en uzun ise 8 yıldır alanda sosyal hizmet uzmanı olarak görev yapmaktadır. 19'u lisans mezunu olan erkek sosyal hizmet uzmanlarının 6'sı ise yüksek lisans yapmıştır. Katılımcıların 10'u yaşlılık ve engellilik, 8 'i aile ve çocuk, 3'ü adli sosyal hizmet, 2'si tıbbi ve 1'i psikiyatrik sosyal hizmet alanlarında çalışmaktadır.

\section{Veri Toplama Süreci}

Araştırmada veri oluşturmak için araştırmacılar tarafından ilgili literatür tarandıktan sonra hazırlanan ve açık uçlu sorulardan oluşan bir anket kullanılmıştır. Açık uçlu anket formu hem nicel hem de nitel araştırmalarda kullanılan bir veri toplama aracıdır. Ancak Patton (2014)'ün de ifade ettiği gibi açık uçlu soruların kullanımı nitel ve nicel araştırmalarda farklılık göstermektedir. Açık uçlu sorulardan elde edilen nicel veriler kısa, sistematik ve standartlaştırılmışken; nitel veriler uzun, detaylı ve içerik açısından daha değişkendir. Açık uçlu sorulardan oluşan anket formunun kullanılmasının en temel sınırlılığı katılımcıların yazım kabiliyetinde eksikliklerin olabilmesi, katılımcıların verdiği cevapların irdelenememesi veya genişletilememesidir. Ancak tüm bu sınırlılıklara rağmen açık uçlu sorular ile katılımcıların bakış açılarıyla dünyayı anlamamıza olanak sağlanması ve açık uçlu sorulara verilen yanıtlarda yansıtılan duyguların derinliği ve detayı, nitel araştırmanın bir ürünü olma niteliği taşımaktadır (Patton 2014). Dört bölümden oluşan açık uçlu anket formu, katılımcıların sosyo demografik bilgileri erkek sosyal hizmet uzmanlarının erkeklik algıları, sosyal hizmet mesleği hakkındaki görüşleri ve toplumsal cinsiyet bağlamındaki mesleki deneyimlerinden oluşmaktadır.

\section{Veri Analizi}

Araştırma verilerinin çözümlenmesinde betimsel analiz tekniği kullanılmıştır. Betimsel analiz; elde edilen verilerin daha önceden belirlenen temalara göre özetlenip yorumlandığı, görüşülen bireylerin görüşlerinin çarpıcı bir biçimde yansıtmak amacıyla sık sık doğrudan alıntıların kullanıldığı ve elde edilen sonuçların neden- sonuç ilişkileri çerçevesinde yorumlandığı analiz tekniğidir (Yıldırım \& Şimşek 2003). Katılımcılardan elde edilen veriler öncelikle araştırmacılar tarafından ayrı ayrı MAXQDA18 nitel veri analizi programına yüklenerek kodlar belirlenmiştir. Farklı farklı yapılan kodlar daha sonra bir araya getirilerek ortak tema ve alt temalara ulaşılmıştır. Analiz sonucunda sosyal hizmet uzmanlarının erkeklik algıları, sosyal hizmetin kadınlara özgü bir meslek olup olmadığına ilişkin algıları ve sosyal hizmet uygulamalarında erkek sosyal hizmet uzmanı olmak temalarına ulaşılmıştır.

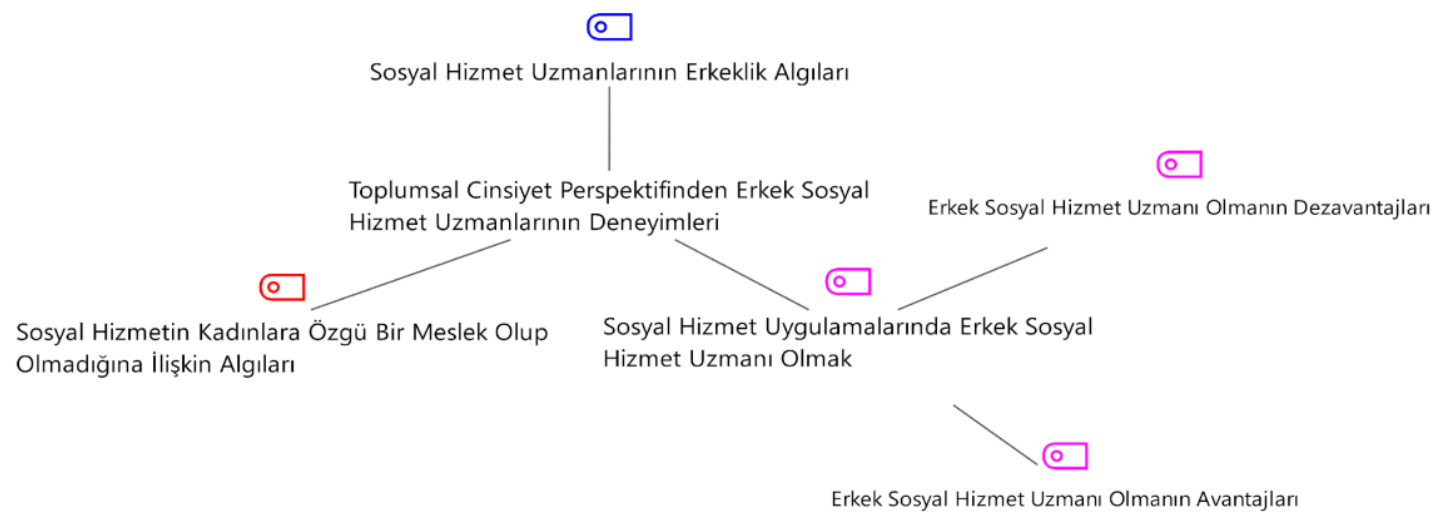

Fig. 1. Araştırma Verilerinin Analizini Gösteren MAXMaps Grafiği 


\section{Sinırlılıklar}

Toplumsal cinsiyetin erkek sosyal hizmet uzmanlarının mesleki yaşamlarına nasıl yansıdığını keşfetmek amacıyla yapılan bu araştırmanın en temel sınırlılı̆̆ 1 verilerin e-posta aracılı̆̆ıyla toplanmış olmasıdır. Araştırmacıların bulundukları yerlerde erkek sosyal hizmet uzmanı sayısının sınırlı olmasından dolayı daha fazla sosyal hizmet uzmanına ulaşma ve veri çeşitliliğini sağlama isteğiyle katılımcılara açık uçlu anket formunun gönderilmesi araştırmanın amacı açısından en uygun veri toplama yöntemi olarak belirlenmiş olsa da süreç içinde çeşitli sorunlarla karşılaşılmıştır. Katılımcıların bazı soruları yanıtsız bırakması, sorulara yüzeysel yanıtların verilmesi, yanıtları detaylandırma ve netleştirme imkânının olmaması en önemli sınırlılıklardır.

\section{Bulgular}

\section{Sosyal Hizmet Uzmanlarının Erkeklik Algıları}

Bir toplumsal cinsiyet kategorisi olarak erkeklik erkekten beklenen rolleri ve erkeğin toplumsal yaşamda nasıl düşünüp, duyup, davranacağını belirleyen pratikler toplamı olarak ifade edilmektedir (Atay 2004). Selek (2008) erkekliğin geleneksel olarak sünnet, askerlik, çalışma, evlilik ve çocuk sahibi olmakla gerçekleştiğinin altını çizmektedir. Sünnet töreni ile çocuğun artık 'erkek' olduğu vurgulanarak tören düzenlenirken aynı durum kız çocukların regl olması sonrasında yapılmamaktadır. Ordu ve/veya askerlik erkekliğin oluşumunda ve yeniden üretilmesinde etkili olan bir diğer önemli kurumdur. Çünkü askerlikte erkeğe güç ve iktidar atfedilmekte (Öztürk 2014), toplumsal cinsiyete dair mesajlarla erkeklik yeniden kurgulanmaktadır. Erkeğin iş bulması ve çalışmaya başlaması erkeklik açısından bir diğer önemli süreçtir. Erkek olmak çalışmak, para kazanmak ve ailesinin ihtiyaçlarını karşılamak anlamına gelir. Bu çerçevede evlilik ve onun ekseninde olan aile kurumu erkekliği yeniden üreten bir diğer kurumdur. Elbette ki her dönemde ve tüm toplumlar için geçerli bir erkeklik tanımı yapmak mümkün görünmemektedir. Bu nedenle de erkeklik yerine erkeklikler kavramının kullanılması gerektiğinin altını çizen Bozok (2011), erkekliklerin farklı stratejiler inşa ederek kadınlar ve queer bireyler üzerinde hegemonya kurduklarını ifade eder.

Toplumsal cinsiyet çalışmalarında önemli bir yeri olan Connell'ın (1998) ortaya attı̆̆ hegemonik erkeklik sahip olduğu bazı özellikleri ile iktidarı elinde bulunduran kimi erkekliklerin kadınlar ve esasında diğer erkekler üzerinde baskı kurduğunu ifade etmektedir. Sancar (2009)'a göre hegemonik erkeklik değerlerini temsil eden küçük bir azınlık erkeğin oluşturduğu bir ortak çıkar alanı içinde birbiriyle ilişkilenebildiğini gösterir; birbirinden çok farklı erkeklik tarzlarının ve her tür kadınlık hallerinin merkezinde erkeklerin olduğu bir iktidar şebekesine eklemlendiği bir düzeni anlatır. Bu çerçevede Türkiye'de hegemonyayı elinde bulunduran erkekler sünnet olmuş, heteroseksüel, askerliğini tamamlamış, bir iş sahibi olan, evlenmiş ve baba olmuş mümkünse de ilk çocuğu erkek olan kişilerdir (Barutçu 2013). Connell'ın hegemonik erkeklik dışında ifade ettiği diğer erkeklikler ise suç ortağı, madun ve marjinal erkeklerdir. Suç ortağ1 erkeklikler, ataerkilliğin inşasında hegemonik erkeklikler kadar aktif bir rol üstlenmemekle birlikte, ataerkilliğe onay vererek kadınların ezilme ve ikincilleştirilmelerinden faydalanırlar. Marjinal erkeklikler ırk, etnisite gibi farklı pozisyonları nedeniyle ataerkil iktidar karşısında hegemonik ve suç ortağı erkeklere göre dezavantajlı konumdadırlar. Madun erkeklikler ise, heteroseksüellik dışındaki cinsel yönelimleri nedeniyle erkek egemenliğinin toplumsal ayricalıklarından en az yararlanan gruptur (Bozok 2009).

Araştırmaya katılan sosyal hizmet uzmanlarının erkeklik tanımlamaları ve kendilerini bu tanımlamada nasıl konumlandırıldıkları sorulduğunda katılımcıların büyük bir çoğunluğunun erkekliği geleneksel cinsiyet rolleri üzerinden tanımlamadığı görülmektedir:

Benim için erkek olmanın belirli bir cinsiyete sahip olma dışında çok fazla anlamı yok. Insan olarak kendimin nasıl gördüğümü konusunda bazı fikirlerim var. Ancak 
nasıl bir erkek olduğumu tanımlama konusunda net bir şey söyleyemiyorum (K4).

Benim için erkek olmak iki cinsiyetten biri olan erkek cinsiyetini ifade etmektedir. Bunun dişında farklı bir şey ifade etmemekte. Kendimi ataerkil toplum ve feminist bakış açısı arsında kalmış bir erkek olarak tanımlıyorum (K7).

Erkekliğin bendeki anlamı bir yolun ikiye ayrllan ayrımlarından sadece biri olabilir. Bu ayrımı kendiniz seçemiyorsunuz. Yani erkeklik bende bir üstünlük, kutsallı olarak algilanmıyor. Dediğim gibi yolun sonuna varmada sadece bir ayrım. Ben kendimi seçmediğim o ayrımda amacına ulaşmak isteyen bir birey olarak tanımlayabilirim (K10).

Erkek olmak benim için bir cinsiyet slfatından başka bir şey ifade etmiyor. Gücü ifade etmiyor, otoriteyi ifade etmiyor. Benim için tek bir sifat var o da insan (K15).

Sosyal hizmet insan hakları ve sosyal adalet ilkelerinden hareketle toplumsal cinsiyet eşitsizliği de dahil olmak üzere her türlü baskı ve ayrımcı pratiklerle mücadele eden bir meslektir. Müracaatçı grupları genellikle kadın ve çocuklardan oluşmakta ve istismar, şiddet gibi toplumsal cinsiyet eşitsizliği ile ilgili sorunlar ise sosyal hizmet uzmanlarının ilgilendiği temel sorunlar olmaktadır. Diğer bir yandan sosyal hizmet öğrencileri sosyal hizmet eğitimi süresince toplumsal cinsiyet konusundaki farkındalıklarının arttırılmasına yönelik dersler de almaktadır. Sosyal hizmet mesleğiyle ilgili tüm bu dinamikler göz önünde bulundurulduğunda erkek sosyal hizmet uzmanlarının toplumsal cinsiyete ilişkin farkındalıklarının olması ve erkekliği geleneksel normlar dışında tanımlamaları beklenen bir durumdur. Diğer bir yandan sosyal hizmet uzmanlarının erkeklik algılarında sosyal hizmet eğitiminin önemli bir etkisi olmakla beraber tek başına belirleyici olduğunu söylemek mümkün değildir. Bireyin yaşadığı toplum, kültürel değerler, yetiştirilme tarzı gibi birçok etken toplumsal cinsiyet algısının şekillenmesinde etkili olmaktadır. Ancak bu çalışmada katılımcıların sosyal hizmet eğitimi öncesinde nasıl bir toplumsal cinsiyet algısına sahip olduğu ve bu algılarının şekillenmesinde nelerin etkili olduğu ele alınmamıştır.

Güç ve iktidar ekseninde kurgulanan erkeklik, erkeklerin yaşamında birçok ayrıcalık sağlasa da beraberinde bir bedel ödemeyi de gerektirmektedir. Erkekler, erkeklik normlarını yerine getirme konusunda toplumsal baskı yaşamaktadır. Bu durum katılımcıların anlatılarında şöyle ifade edilmektedir:

Bana göre erkek olmak dünyanın en zor şeylerinden biri olabilir. Bunun nedeni olarak toplumsal cinsiyet rollerini reddetmemi gösterebilirim. Erkek; ev işi yapmaz, daha sert olur, kadına karşı üstündür gibi kalıpları reddetmek toplum tarafindan bir bask görmeme neden oluyor. Bu nedenle ben kendimi ve toplumdaki tüm bireyleri cinsiyetlerin toplumda yarattlğı kötülükten dolayı insan olarak tanımlıyorum ya da tanimlamak istiyorum (K5).

Toplumumuzda erkek olmak her ne kadar güç ve imtiyaz olarak görülse de, bence toplumsal baskinın altında olmaktır. Çünkü toplumsal cinsiyet rolleri erkeğe de birçok yük yüklemiş(evin geçimi, ihtiyaçlar vb.), bunları yerine getiremeyen erkekler şiddete başvurabilmektedir. Bence, erkek olmak insanın seçmediği bir şey olduğu için sadece bir cinsiyettir...(K8).

Sonuç olarak araştırmaya katılan erkek sosyal hizmet uzmanlarının ataerkil bir toplumda yaşamalarına rağmen sosyal hizmet mesleğinin insan hakları ve sosyal adaleti temel alan doğası gereği toplumsal cinsiyete dayalı eşitsizliklerin farkında olduğu ve toplumsal cinsiyet rollerine yönelik eleştirel bir duruş sergiledikleri söylenebilir. 


\section{Sosyal Hizmetin Kadınlara Özgü Bir Meslek Olup Olmadığına İlişkin Algıları}

"Saldırganlık", "girişkenlik" gibi erkeklikle ilişkilendirilen özellikler erkekleri iş dünyası ve politika hayatında daha etkin hale getirmektedir. "Uysal", "edilgen" ve "bağımlı" gibi özelliklerle ilişkilendirilen kadınlık ise kadınların özel alana, çocuk bakımı ve yetiştiricilik rolüne itilmesine neden olmaktadır (Günindi-Ersöz 2015). Dolayısıyla hemşirelik, öğretmenlik ve sosyal hizmet gibi bakım meslekleri geleneksel yapı içerisinde genellikle feminen olarak görülmektedir. Bundan dolayı tarih boyunca erkeklerin bu alanlara girmesi zorlu olmuştur. Aynı şekilde tarihsel süreç içerisinde erkek mesleklerine yönelmek kadınlar için de sosyal ve kültürel açıdan zorlayıcı olabilmektedir (Khunou et al. 2012). Bu durum cinsiyete dayalı işbölümün bir yansımasıdır. Araştırmaya katılan erkek sosyal hizmet uzmanlarının cinsiyete özgü meslekler ile ilgili düşünceleri sorulduğunda büyük bir çoğunluğu cinsiyete özgü meslek olmadığını ifade etmiştir:

Cinsiyete özgü meslek olduğunu düşünmüyorum. Bütün meslekleri hem erkekler hem de kadınlar yapabilir. Sosyal hizmet mesleğinin her iki cinsiyete uygun olduğunu düşünüyorum (K22).

Günümüz dünyasında kadın veya erkek kim olursa olsun sağllklı olduğu takdirde her mesleği icra edebilir. Sosyal hizmetin de ayn şekilde hem kadin hem de erkek perspektifine ihtiyaç duyan bir meslek olduğu kanaatindeyim (K18).

Cinsiyete özgü meslekler olduğunu düşünmüyorum. Böyle bir durum zaten kadın erkek eşitsizliğine neden olur. Toplumsal cinsiyet algısını doğurur. Kadınlar şunu erkekler şunu daha iyi yapar diye bir durum söz konusu olmadı̆̆ını düşünüyorum. Kadın güçsüz şu işleri yapamaz algısının yanlış olduğunu düşünüyorum. Kadına veya erkeğe uygun meslekler toplumsal cinsiyet kavramıyla oluşmuş algılar. Toplumun beklentileriyle, toplumsal cinsiyetle süreç içerisinde kadının ve erkeğin meslek seçimi belirli bir alana doğru kaymuştır. Hemşirelik örneği gibi veya şoförlük gibi. Sosyal hizmet mesleğinin bu anlamda toplumsal cinsiyet algisiyla belirli bir yere konulduğunu düşünmesem de gerek tarihsel süreç ve mesleğin gelişim süreci, gerekse günümüzde kadınların daha fazla tercih ettiği söylenilebilir. Tabiki bu durum en nihayetinden toplum cinsiyet algisl ve kadından erkekten beklentisiyle açıklanabilir (K13).

Cinsiyete özgü meslekler olduğunu düş̈̈müyorum. Her mesleği kadın ya da erkek yapabilir. Fakat bazı mesleklerin daha sık kadın ya da erkekler tarafindan yapılması bunu bir gruba özgü gibi göstermekte. Sosyal hizmeti belli bir cinsiyete özgü bir meslek olarak görmüyorum (K7).

Bazı katılımcılar ise cinsiyete özgü meslekler olduğunu ancak sosyal hizmetin bu bağlamda değerlendirilemeyeceğini vurgulamaktadır:

Elbette özgü meslekler var. Anaokulu ögretmenliğini ve çocuk gelişimcilerin kadınlara özgü olduğunu düşünüyorum. Mühendislik (gıda ve peyzaj hariç) genel itibariyle erkeklere daha uygun olduğunu düşünüyorum. Sosyal hizmet insanı temel alan bir meslek olduğundan tek bir cins tarafindan yapılması mümkün değildir. Kadınların ve erkeklerin etkin müdahale edebildiği düşünebildiği farklı durumlar vardır. Müracaatçıların da sosyal hizmet gibi önem arz eden durumlar özel bilgilerini paylaşırken aynı yada farklı cinsten bir shu'ya (sosyal hizmet uzmanına) farkl şekilde anlatabilir (K11).

Cinsiyete özgü meslekler olduğunu düşünüyorum. Şu şekilde ifade edebilirim. Özellikle fiziksel gücün kullanımı ile ilgili farklılığa gidilebilir meslek seçiminde. Örneğin inşaat işçiliği. Ancak cinsiyet rolleri sebebiyle böyle bir ayrım yapmadr- 
ğımı açıkça belirtmek isterim. Diğer yandan her ne kadar Avrupa'da kadın odaklı bir meslek olarak gözükse de ben sosyal hizmet mesleğini bu bă̆lamda değerlendirmiyorum. Çünkü bu mesleğin icra edilmesi cinsiyetle ilişkilendirilemez. İnsana saygılı ve insan haklarını temel alan bir anlayışa bağlı her kişinin bu mesleği icra edebileceğini düşünüyorum (K15).

Sosyal hizmetin kadınlara özgü bir meslek olarak algılanmasının nedenleri arasında sosyal hizmetin odağında bakım olan bir meslek olması ve bakım meselesinin de kadınlıkla ilişkilendirilmesiyle ilgili olduğu söylenebilir. Nitekim araştırmaya katılan erkek sosyal hizmet uzmanları da sosyal hizmet mesleğinin daha çok kadınlar tarafından yerine getirilmesini toplumsal cinsiyet rolleri nedeniyle kadınlara yüklenen bakım rolü ile ilişkilendirmişlerdir:

Sosyal hizmet mesleğinin kadinlar tarafindan yerine getirilmesini, toplumsal cinsiyet rolleri tarafindan kadınlara verilen bakım rolü ile ilişkilendirebilirim. Onaylamadı̆̆ım ve kabul etmediğim bir durumdur bu. Yukarıda da belirttiğim gibi bu mesleğin cinsiyetle ilişkilendirilmesi mümkün değil (K15).

"Hizmet” sözcü̈ğü ülkemizde kadınla bağdaştırıldı̆̆ iç̧in o kelimenin bile iş seçiminde çok etkili olduğunu düşünüyorum. Anaokulu öğretmenlerinin hep kadın olması gibi (K2).

Türkiye Sosyal Hizmet Uzmanları Derneği'ne (SHUDER) göre 2015 yılında Türkiye'de toplam 6150 sosyal hizmet uzmanı bulunmaktadır (http://shuder.org/sosyalhizmet/sh8.html). Derneğin çalışmasında cinsiyete dair bir ayrıma rastlanmamıştır. YÖK Program Atlası'na göre Türkiye'de sosyal hizmet eğitimi veren devlet veya vakıf üniversitelerin hemen hemen hepsinde kadın ögrencilerin sayısı erkeklerden fazladır. Türkiye'de 1961-2002 yılları arasında sadece Hacettepe Üniversitesi'nde verilen sosyal hizmet eğitimi giderek yaygınlaşmıştır. Çalışma alanlarında her iki cinsiyetten sosyal hizmet uzmanına yoğun gereksinim duyulduğu için uzun yıllar bölüme kız ve erkek öğrenciler eşit sayıda alınmıştır (http://www.shy.hacettepe.edu.tr/tr/menu/lisans_ ogretim_programlari-18). Ancak 2015 yılı ÖSYM Kılavuzu incelendiğinde böylesi bir eşitliğin güdülmediği ve toplamda 180 öğrenci alındığı görülmüştür. Bu iki durum göz önüne alındığında sosyal hizmet öğrencilerinde ve dolayısıyla mezunlarında kadın sayısının fazla olduğu söylenebilir. Öte yandan ABD 'de hazırlanan sosyal hizmet uzmanı işgücü profili raporuna göre (Salsberg et al. 2017) 2015 yılında lisans mezunu kadın sosyal hizmet uzmanı oranı \%83'dür ve kadınların oranı gittikçe artmaktadır. 2011 yılında Afrika Sosyal Hizmet Mesleği Konseyi’ne kayıtlı kadın sosyal hizmet uzmanı oranı \%85 iken, kadın öğrencilerin oranı ise \%70'dir (Khuno et al. 2012). Oranlardan da görüldüğü üzere hem ulusal hem de uluslararası düzeyde kadın sosyal hizmet uzmanlarının sayıca çoğunlukta olması sosyal hizmetin kadınlara özgü mesleklerden biri olarak algılanmasının önemli nedenlerinden biridir. Diğer bir yandan araştırmaya katılan sosyal hizmet uzmanları, kadınların toplumsal cinsiyet eşitliğinden kaynaklı olarak dezavantajlı konumda olmalarının da böyle bir algının oluşmasında etkili olduğunun altını çizmektedir:

Kadınlar neredeyse bütün toplumlarda tarihsel olarak hemen her zaman dezavantajlı gruplar olmuştur. Bu sebeple kadınların ön plana çıkıyor olmasını anormal bulmuyorum ancak kadınların sosyal politikalar oluşturulurken özellikle karar alma süreçlerinde bu rolü erkeklerin elinden yeterince alamadıklarını düşünüyorum (K9).

Çünkü toplumda daha çok mağdur ve mazlum olan her zaman kadınlar olmuştur. Savaşlar, afetler en çok kadınları etkilemiştir. Aynı zamanda kadınlar bütün haklarını erkeklerden sonra elde etmiştir. Bu nedenle hak arama, eşitlik ve adalet çalışmalarına kadınların ilgisi daha fazla yoğunlaşmıştır (K8). 
Toplumsal cinsiyetin bir yansıması olarak kadınlık duygusal, sevecen, şefkatli olma gibi özelliklerle tanımlanmaktadır. Araştırma katılımcıları da söz konusu tanımlamaların kadınların sosyal hizmet mesleğinde çoğunluğu oluşturmasında ve mesleği yaparken avantaja sahip olmasinda etkili olduğunu düşünmektedir:

\section{Kadınların daha duygusal olması sebebiyle bu mesleğin kadınlar tarafindan yerine getirilmiş olduğunu düşünüyorum (K23).}

Erkek savaşçı kadın destekçi şefkatli yardımsever. Dolayısıyla kadınları hizmet ve yardımlarda görmek daha kolay olmuştur (K13).

Kadınlarda var olan annelik güdüsü nedeniyle daha şefkatlidirler. Bu nedenle kadınlar daha fazla sosyal hizmet mesleğini yerine getirmiştir (K7).

Merhamet ve şefkat duygusu da müdahalelerde esastır, kadınların bu duygularının daha fazla gelişmiş ve ön plana çıkarılmış olduğunu düşündüğümüzde mesleğin doğası kadınlara avantaj sağlamış olabilir (K6).

Erkek sosyal hizmet uzmanlarının sosyal hizmetin kadınlara özgü bir meslek olup olmadığına ilişkin ifadelerine bakıldığında, cinsiyete özgü meslekler olduğunu ifade eden katılımcılar olsa da katılımcıların büyük bir çoğunluğu cinsiyete özgü meslekler olmadığını ve bu kapsamda sosyal hizmetin de kadınlara özgü bir meslek olarak değerlendirilemeyeceğini vurguladığ görülmektedir. Diğer bir yandan kadınların tarihsel süreç içinde sosyal hizmet mesleğinde daha fazla yer almalarında onların "duygusal", "şefkatli ve yardımsever", merhametli" olmalarının etkisi olduğu ifade edilmektedir. Erkek sosyal hizmet uzmanlarının söz konusu söylemleri, cinsiyete özgü meslekler tartışmasında geleneksel cinsiyet rolleriyle uyumlu bir duruş sergiledikleri ve bu durumun bir önceki temada aktarılan erkekliği tanımlama ve algılama biçimleriyle örtüşmediği sorusunu gündeme getirmektedir. Tam zamanlı bir işe sahip olmanın hegemonik erkekliğin gerekliliklerinden olduğu göz önüne alındığında birbiri ile örtüşmeyen söylemlerin, tarihsel süreçte daha çok kadınların var olduğu bir alanda Gönç'ün (2016) çalışmasında da gösterdiği gibi erkeklerin varlığını meşrulaştırmaya çabasına hizmet ettiği söylenebilir. Nitekim erkek sosyal hizmet uzmanlarıyla yaptığı çalışmasında Açıl (2019) da, erkeklerin özel yaşantılarında kısmen cinsiyetçi yaklaşımlara ve çelişik (karşı cinse karşı korumacı ve düşmanca yaklaşım ve eylemlerin bir arada bulunması) cinsiyet duygu durumlarına sahip bireyler olduklarını saptamıştır.

\section{Sosyal Hizmet Uygulamalarında Erkek Sosyal Hizmet Uzmanı Olmak}

Williams (1995 akt. Pease 2011) erkek sosyal hizmet uzmanlarının cinsiyetlerinden dolay1 meslek içerisinde avantajlara ve dezavantajlara sahip olduğunu belirtmektedir. Çünkü erkekler toplumsal hayatta sahip olduğu güç ve ayrıcalıklarını meslek içerisinde de sürdürme eğiliminde olabilmektedir. Erkek baskın mesleklere kadınların kabul edilmesindeki zorluklara ve isteksizliklere rağmen kadın meslektaşlar erkeklerin sosyal hizmet mesleğini yerine getirmesini genellikle sıcak karşılamakta ve onları desteklemektedir. Bu çalışmaya katılan erkek sosyal hizmet uzmanları ise farklı açılardan hem avantajı hem de dezavantajlı olduklarını belirtmektedir. $\mathrm{Bu}$ doğrultuda sosyal hizmet uygulamalarında erkek sosyal hizmet uzmanı olmak teması erkek sosyal hizmet uzmanı olmanın avantajları ve erkek sosyal hizmet uzmanı olmanın dezavantajları olmak üzere iki alt tema çerçevesinde ele alınmaktadır.

\section{Erkek Sosyal Hizmet Uzmanı Olmanın Avantajları}

Sosyal hizmet uzmanları, sosyal hizmet uygulamaları sırasında genellikle öfkeli, stresli ve şiddet eğilimi olan müracaatçılarla çalıştığından kimi zaman tehlikeli durumlarla karşılaşabilmekte ve risk altında olabilmektedir. Söz konusu müracaatçılar ceza mahkemesi ortamlarında, 
çocuk koruma, ruh sağlığı hastaneleri ve bağımlı tedavi programlarında bulunabilmektedir (Sheafer \& Horejsi 2014). Araştırmaya katılan erkek sosyal hizmet uzmanları da sosyal hizmet uygulamaları sırasındaki olası tehlikelerin üstesinden gelme hususunda avantajlı olduklarını ifade etmektedir:

Şizofreni gibi kişilik bozukluğu olan kişilerle yapılan görüşmelerde erkek sosyal hizmet uzmanlarının avantajlı olabileceğini düşünüyorum (K23).

Sanırım bazı kritik ve tehlikeli vakalarda kadinlardan daha az korkuyoruz tek avantajımız budur (K2).

Bazı müracaatçılarla iletişim kurmada kolaylık sağllyor. Erkek psikiyatri hastalarıyla iletişim kurarken erkek olmamdan dolayı rahatça iletişim kurabiliyorum (K7).

Sosyal hizmet uzmanlarının tehlikeli durumlarla karşılaş̧ma olasılığının olduğu sosyal hizmet faaliyetlerinden biri de sosyal incelemelerdir. Sosyal hizmet uzmanları sosyal inceleme yapmak amacıyla müracaatçıların ev, ișyeri gibi yașam alanlarında bulunmakta ve bu süreçte çeșitli riskli durumlarla karşılaşabilmektedir. Araştırmaya katılan erkek sosyal hizmet uzmanları sosyal incelemelerde olası tehlikelerle baş etme noktasında avantaja sahip olduğunu belirtmektedir:

Yaptığım incelemelerde girdiğim evlerde daha rahat bir şekilde iletişim kurabilme imkanın yakalayabiliyorum. Daha cesaretli davranabiliyorum (K14).

Deneyimlerim güvenlik duygusu anlamında avantajlar sağladı̆̆ yönünde. Örneğin eski çalıştığım yerde çoğunlukla yaşanılan ortamı incelemeye giderken tek başıma çok fazla çekinmeden gidebileceğimi düşünüyordum. Birlikte çalıştığım kadın meslektaşların ise bu konuda önemli kaygılarının olduğunu görüyordum (K4).

Sosyal hizmet mesleğinin en önemli ayaklarından birisi sosyal incelemedir. Bu süreçte kişinin yaşamını sürdürdüğ̈̈ yer neresi ise oraya gözlem, değerlendirme ve görüşme için gidilir. Biz sosyal hizmet uzmanları her ne kadar özel gereksinimi olan kişilerle çalışsak da aynı zamanda çalıştığımı grubun riskli özellikleri de olabiliyor. Özellikle şiddet ve suç unsuru içeren vakalarda bu risklerle karşılaşabiliyoruz. Bu noktada erkek olmamın avantajını zaman zaman yaşadığımı söyleyebilirim. Sirf erkek olduğum için saygı duyulduğum ve kabul gördüğ̈̈mü söylemem mümkün (K15).

Güç ve iktidar erkeklikle ilişkilendirilmekte, erkekliğin inşasında ve yeniden üretiminde önemli bir yere sahip olmaktadır. Bu durumun yansımalarını kişilerarası ilişkilerde de görmek mümkündür. Erkekler erkekliğin güç ve iktidar ile ilişkilendirilmesi nedeniyle kişilerarası ilişkilerinde kadınlara göre daha fazla otorite olarak görülmektedir. Araştırmaya katılan erkek sosyal hizmet uzmanları da sosyal hizmet uygulamaları sırasında müracaatçılarla kurdukları etkileşimde kadın meslektaşlarına göre daha fazla saygı gördüklerini ve bir otorite olarak görüldüklerini ifade etmektedir:

Olumlu düzeyde etkiliyor. Erkek duruşu insanlara güven veriyor bence. Kendilerini güvenli bir ortamda hissedip kendilerini rahatça ifade edebiliyorlar (K25).

Sanırım erkek olduğum için, kadın meslektaşlarımdan daha fazla saygı duyuluyorum. Farklı etkenler de olabilir ama cinsiyetimin bunda önemli olduğunu söyleyebilirim. Mesela aynı odada çalışan bir erkek bir kadın iki sosyal hizmet uzmanıyız. Içeriye giren müracaatçı (kadın veya erkek) çok büyük bir oranla doğrudan benimle iletişime geçmeye çalışıyor (K15)

Erkek olmak daha sert otoriter görülmenize ve daha fazla dinlenmenize neden 
olabilir. Toplumsal cinsiyet algısından dolayı mesleki çalışmalarımda daha fazla dikkate alındı̆̆ımı deneyimledim (K13).

Toplum yapısında kadınların genel itibariyle kırllgan olarak görülmesi ve duygusallıklarının yüksek olmasinın, kriz anlarında veya olayın inceliklerindeki detayların yakalamasında daha fazla etkili olduğumuzu düşünmekteyim. Kadın meslek elemanlarının kabul edilsin edilmesin erkeğin fiziken güçlü olmasının psikolojik olarak müracaatçı görüşmelerinde güven hissiyatı ve problem çözücü olarak olumlu geri dönütler vermektedir (K11).

Özellikle kamuda çalışmalarda müracaatçılar sizi daha otoriter ve daha yetkili olarak görebiliyorlar (K3).

Katılımcıların sosyal hizmet uygulamalarında erkek olmanın avantajlarına yönelik ifadelerine bakıldığında hegemonik erkekliğin izlerini görmek mümkündür. Korkusuzluk, güçlü olma, otorite olarak görülme gibi ifadeler erkek sosyal hizmet uzmanlarının sosyal hizmet uygulamalarında hegemonik erkeklik normları üzerinden avantajlı bir konum elde ettiklerini göstermektedir.

\section{Erkek Sosyal Hizmet Uzmanı Olmanın Dezavantajları}

Sosyal hizmet uygulamalarında erkek sosyal hizmet uzmanı olmanın çeşitli avantajları olabileceği gibi bazı dezavantajları da söz konusudur. Bu dezavantajlardan biri de erkek sosyal hizmet uzmanlarının kadın müracaatçılarla olan iletişim ve etkileşimlerinin sınırlandırılmasıdır:

Görüşmelerde kadın müracaatçılarla daha zor iletişim kuruyorum. Hatta küçük kız çocuklarıyla yanımda bulunan kadın shu daha etkili iletişim kurabiliyor. Kadınlar sorunlarını anlatırken açık konuşamıyorlar benimle. Eve girip haneyi gözlemleyemiyorum bazen kapıda görüşme yapmak durumunda kalıyorum (K6).

Kimi zaman kadın müracaatçıların dertlerini ve sorunlarını vs. (yaşam deneyimlerini) aktarma konusunda çekingen tavırlar sergilediklerini veya paylaşmak istemediklerini hissettim. Bir defasında kadın meslektaşımla ortak yaptı̆̆ımız görüşme esnasında müracaatçı paylaşacağı şeyin özel olduğunu (cinsel bir yaşam deneyimi ile ilgili) ve yalnızca kadın meslek elemanına anlatmak istediğini belirtmiştir. Bu nedenle odadan ayrlmışım (K4).

Erkek sosyal hizmet uzmanları sosyal incelemeler sırasında ortaya çıkabilecek tehlikeli durumlarla baş etme noktasında bir avantaja sahip olduğunu ifade ederken, kadın müracaatçılar söz konusu olduğunda bu avantajın dezavantaja dönüştüğünü vurgulamaktadır:

Mesela ben sosyal ekonomik destek başvurusu yapan müracaatçllara sosyal inceleme amacıyla ikamet adreslerine giderim. Genellikle bu yardımı alanlar küçük çocukları olan eşi cezaevinde olan eşi vefat etmiş olan ve eşinden ayrı kadınları desteklediğimiz bir yardım türü. Fakat bazen incelemeye gittiğimde erkek olduğun için içeriye almak istemiyorlar (K2).

Yapılan incelemelere erkek grubu olarak gitmek incelemeye gidilen evde tek bayan varsa yanlış anlaşılmalara yol açabileceğinden dezavantaj olarak değerlendirilebi$\operatorname{lir}(\mathrm{K} 24)$.

Sosyal inceleme için sadece kadınların olduğu bir eve girerken toplumun cinsiyet algısı erkek shu'nun o eve girmesini imkânsı ayıp zor kılabilir. Tam tersi durumları da düşünmek mümkündür (K13). 
Sosyal hizmet uzmanlarının mücadele ettiği temel sorunlardan olan istismar ve şiddetin failleri genellikle erkektir. Bu durum erkek sosyal hizmet uzmanlarının istismar ve şiddet mağdurlarıyla çalışırken mağdurların rahat ve güvende hissedememesine neden olabilmektedir:

\section{Çocuk Şubeye gelen vakalardan cinsel istismar konusunda çocuğun kendisini erkek bir sosyal hizmet uzmanına açmasının daha zor olacağını düşünmekteyim (K21).}

\section{Çocuğa istismar konularında genellikle erkekler tarafindan yapıldı̆̆ için istismara uğrayan çocukların erkek personelle konuşmadiğı gözledim. Yabancı her erkekten zarar gelecek gözle baklyorlar. Çocukların gözlerinden o korkuyu anlayabiliyorsun (K2).}

Erkek sosyal hizmet uzmanları sosyal hizmet uygulamalarında kadın müracaatçılarla görüşme yaparken, kadın müracaatçıların evinde sosyal inceleme yaparken, şiddet ve istismar vakalarıyla mesleki çalışmalar yürütürken dezavantajlı olduklarını ifade etmektedir. Erkeklerin dezavantajlı oldukları durumlarda tıpkı avantajlı konumda oldukları durumlarda olduğu gibi hegemonik erkekliğin yansımaları söz konusudur. Nitekim Moffat (2004) de erkek sosyal hizmet uzmanlarını sosyal hizmet mesleği kapsamında olan ilişkilerdeki sosyal mesafenin saygı ve sınır korumanın bir biçimi mi yoksa zaman zaman eril ayrıcalığg korumanın bir yöntemi mi olduğunu sorgulamaya davet etmektedir.

\section{Sonuç}

Sosyal hizmet, tarihi 1800'li yıllara dayanan gönüllülük ve hayırseverlik ile başlayan, ardından meslek olma yönünde üniversitelerde eğitim yolu açllan profesyonel bir meslektir. Profesyonelleşme sürecinden önce merhamet, yardımseverlik, şefkat, iyilik gibi duygular işin temelini oluşturmuştur. Toplumsal cinsiyet rollerinden ötürü bu duygular kadın ile özdeştirilmekte, erkekler duyguların dişında tutularak akıl ve mantık ile ilişkilendirilmektedir. Bu bakış açısı çocukluktan itibaren başlayarak bireylerin yaşamlarını etkilemektedir. Meslek seçimi de bireyin yaşam döngüsünde önemli bir yere sahiptir.

Sosyal hizmet insan hakları ve sosyal adaleti odağına alarak bireylerin gereksinimlerini karşılamayı ve güçlendirilmesini hedefleyen bir meslektir. Sosyal hizmete ihtiyaç duyanlar kadın, engelli, yaşlı, çocuk, hasta, madde bağımlısı gibi dezavantajlı gruplardır. Dolayısıyla toplumsal cinsiyet rollerine dayalı olarak bakım verme kadına ait bir iş olarak algılandığından sosyal hizmet mesleğinin temel aktörleri kadınlar olarak görülmektedir. 1961-2002 yılları arasında Türkiye'de sosyal hizmet eğitimi veren tek okul olan Hacettepe Üniversitesi Sosyal Hizmet Bölümü, çalışma alanlarında her iki cinsiyetten çalışana ihtiyaç duyulması gerekçesiyle cinsiyete dayalı kota koyarak eşit sayıda erkek ve kadın öğrenci almışır. Ancak bu uygulama yakın bir geçmişte sonlandırılmıştır. 2018 yılı YÖK Program Atlası'na bakıldığında sosyal hizmet bölümlerine yerleşenlerin çok yüksek bir oranının kadınların oluşturduğu görülmektedir. $\mathrm{Bu}$ da sosyal hizmetin ağırlıklı olarak kadınlar tarafından tercih edildiğini göstermektedir.

McPail (2004) mesleği kadın ağırlıklı ancak erkek baskın bir meslek olarak tanımlamaktadır. Bu doğrultuda erkeklerin sosyal hizmet mesleği içindeki konumu muğlak ve tartışmalı bir hal almaktadır. Bu noktadan hareketle bu çalışmada erkek sosyal hizmet uzmanlarının mesleki yaşamlarına toplumsal cinsiyetin nasıl yansıdığını keşfedilmesi amaçlanmıştır. Analiz sonucunda erkeklik algıları, sosyal hizmetin kadınlara özgü meslek olup olmamasına ilişkin algıları ve uygulamada erkek sosyal hizmet uzmanı olmak temalarına ulaşılmıştır.

Erkek sosyal hizmet uzmanlarının erkeklik algılarına bakıldığında söylemlerinde para kazanmak, sert ve güçlü olmak, mantığıyla hareket etmek, ailesini koruyup kollamak gibi geleneksel erkeklik rollerinden farklı bir profil çizdikleri görülmektedir. Analizlerde katılımcıların tamamının bu doğrultuda yanıt verdikleri görülmüştür. Hatta içlerinden çok az bir kısmı da olsa (2 kişi) bu geleneksel toplumsal cinsiyet rollerine uymayan erkeklerin 'toplumun baskisına' maruz 
kaldıklarını ifade etmektedir. Odağına insan hakları ve sosyal adaleti alan sosyal hizmet mesleği için toplumsal cinsiyete dayalı eşitsizliklerle mücadele etmek, cinsiyetçi pratiklerin yeniden üretilmesine engel olmak oldukça önemli bir yer tutmaktadır. Erkek sosyal hizmet uzmanlarının bunu yapabilmesi hiç şüphesiz toplumsal cinsiyete duyarlı olmaları ve hegemonik erkeklik normlarına eleştirel bir duruş sergilemesiyle yakından ilişkilidir. Elbette ki sosyal hizmet eğitiminin tek başına toplumsal cinsiyete duyarlı bir bakış açısı sağladığı söylenemez. Ancak yine de katılımcıların bu söylemleri sosyal hizmet mesleğinin temel değerleri açısından önemlidir.

Sosyal hizmetin kadınlara özgü bir meslek olup olmadığına ilişkin algılarına bakıldığında mesleğin tarihsel gelişimine atıfla kadınların ağırlıkta olmasının o mesleği kadınlara özgü olduğunu göstermediği ve sosyal hizmet uygulamalarında erkeklere de ihtiyaç duyulduğu belirtilmektedir.

Sosyal hizmet mesleğin uygulamasında erkek sosyal hizmet uzmanlarının bir takım avantaj ve dezavantajlara sahip oldukları belirlenmiştir. Buna göre araştırmaya katılan erkek sosyal hizmet uzmanları sosyal hizmet uygulamaları sirasında riskli ya da tehlikeli olabilecek durumlarla kadın meslektaşlarına oranla daha kolay başa çıkabilmeleri, erkek oldukları için daha çok dikkate alınmaları ve saygı duyulmaları noktasında avantajlı olduklarını düşünmektedir. Diğer bir yandan erkek sosyal hizmet uzmanları açısından kadın müracaatçılarla iletişimimde sorun yaşamaları, erkeklerin şiddet ya da istismar failleri oldukları için kendilerinin erkek olmasından dolayı kadın müracaatçılarla çalışmada sorun yaşadıkları/yaşayabilecekleri, sosyal inceleme yapılan hanede erkeğin olmadığı durumlarda eve girememe dolayısıyla ev incelemesini yapamama gibi dezavantajların da olduğu vurgulanmaktadır. Katılımcıların sosyal hizmetin kadınlara özgü bir meslek olup olmadığına ve uygulamada erkek sosyal hizmeti uzmanı olmaya ilişkin algılarında ifade ettikleri durumların erkeklik algıları ile örtüşmediği göze çarpmaktadır. Alıntılarda erkeklerin her ne kadar toplumsal cinsiyet rollerine eleştirel bir duruş sergiledikleri görülse de kullandıkları "duygusal", "şefkatli ve yardımsever", "merhametli", "korkmama", "cesaretli olma", "sayg1 görme", otorite görme" gibi ifadeler onların hegemonik erkekliğin izlerini taşıdıklarını göstermektedir. Bu yönüyle araştırmanın Açıl'ın (2019) çalışmasıyla belli düzeyde örtüştügüün söylemek mümkündür.

Sonuç olarak sosyal hizmetin kadınlar kadar erkekler tarafından da yerine getirilmesi müracaatçılar ve sunulan hizmetler açısından önemlidir.. Ancak sosyal hizmet mesleğinin özgürleştirici ve baskı karşıtı uygulamayı gerçekleştirme misyonu göz önünde bulundurulduğunda, erkek sosyal hizmet uzmanlarının toplumsal cinsiyete duyarlı olması ve geleneksel cinsiyet rollerine mesafeli bir tutum sergilemesi gerekmektedir. Pease'in (2011) de ifade ettiği gibi sosyal hizmetin hegemonik erkekliği eleştiren ve erkeklerin imtiyaz ve haksız kazanımlarıyla ilişkili cinsiyete dayalı adaletsizliklerin farkında olan daha çok erkek sosyal hizmet uzmanına ihtiyacı vardır. Bununla birlikte erkek sosyal hizmet uzmanları aktif olarak profeminist uygulamaları teşvik etmiyorsa, meslek içinde eşit olmayan bir toplumsal cinsiyet rejimi üreteceklerdir. Dolayısıyla sosyal hizmet eğitiminde toplumsal cinsiyet eğitiminin zorunlu olarak verilmesi ve sosyal hizmet öğrencilerinin mezun olmadan önce toplumsal cinsiyet konusunda belirli bir farkındalığa ve yetkinliğe sahip olmasının sağlanması gereklidir. Son olarak konuyla ilgili olarak sosyal hizmet uzmanları, sosyal hizmet öğrencileri ve sosyal hizmet akademisyenlerini odağında bulunduran araştırmalara ihtiyaç olduğu düşünülmektedir.

\section{Yazarın Notu}

Yoğun çalışma temposuna rağmen bu çalışmaya katılmayı kabul eden sosyal hizmet uzmanlarına teşekkür ederiz. 


\section{KAYNAKÇA}

Açıl E. (2019). Erkek Sosyal Hizmet Uzmanlarının Erkeklik Algısı Üzerine Bir İnceleme. Yüksek Lisans Tezi. Dokuz Eylül Üniversitesi, İzmir 2019.

Atay T. (2004). "Erkeklik En Çok Erkeği Ezer". Toplum ve Bilim 101 (2004) 11-30.

Avcı Ö. H., Karababa A. \& Zencir T. (2018). "Toplumsal Cinsiyet Bağlamında Erkek Okul Öncesi Öğretmen Adayları: Algıladıkları Güçlükler ve Gelecek Kaygıları”. Hacettepe Üniversitesi Eğitim Fakültesi Dergisi (2018) 1-15.

Barutçu A. (2013). Türkiye’de Erkeklik İşasının Bedensel ve Toplumsal Aşamaları. Yüksek Lisans Tezi. Ankara Üniversitesi, Ankara 2013.

Başçı A. B. \& Yılmazel G. (2016). "Genç Erişkinlerin Erkek Hemşirelere Bakış Açısı". Hemşirelikte Akademik Araştırma Dergisi 2/2 (2016) 68-74.

Bozok M. (2009). "Erkeklik İncelemeleri Alanındaki Başlıca Kuram ve Yaklaşımların Sosyalist Feminist Bir Eleştirisine Doğru”. 6. Ulusal Sosyoloji Kongresi Bildiri Kitabı (2009) 431-445. Aydın.

Bozok M.(2011). Soru ve Cevaplarla Erkeklikler. İstanbul 2011.

Chambers C. A. (1986). "Women in the Creation of the Profession of Social Work". Social Service Review 60/1 (1986) 1-33.

Christie A. (1998). "Is Social Work a 'Non-Traditional' Occupation for Men?". The British Journal of Social Work 28/4 (1998) 491-510.

Christie A. (Dü.). (2001). Men and Social Work: Theories and Practices. London 2001.

Connell R. (1998). Toplumsal Cinsiyet ve İktidar. Çev. C. Soydemir. İstanbul 1998.

Creswell J. W. (2013). Nitel Araştırma Yöntemleri. Ankara 2013

Erer M. T., Kanat C. \& Öğer E. Ş. (2017). "Toplumun Erkek Hemşirelere Bakışı: Mersin Örneği”". Uluslararası Hakemli Hemşirelik Araştırmaları Dergisi (2017) 137-156.

Gönç T. (2016). "Kadın Yoğun Meslekleri Erilleştirmeye Yönelik Stratejiler: Türkiye’de Erkek Hemşireler Örneği”. Sosyoloji Araştırmaları Dergisi 19/1 (2016) 96-144.

Günindi-Ersöz A. (2015). “Özel Alan / Kamusal Alan Dikotomisi: Kadınlığın "Doğası” ve Kamusal Alandan Dışlanmışlığı”. Sosyoloji Araştırmaları Dergisi 18/1 (2015) 80-102.

Hacettepe Üniversitesi Sosyal Hizmet Bölümü. (n.d.). http://www.shy.hacettepe.edu.tr/tr/menu/tarihce-108. Erişim tarihi:09.09.2019.

Hicks S. (2015). "Social Work and Gender:An Argument For Practical Accounts". Qualitative Social Work 14/4 (2015) 471-487.

Kahraman A., Tunçdemir N. O. \& Özcan A. (2015). "Toplumsal Cinsiyet Bağlamında Hemşirelik Bölümünde Öğrenim Gören Erkek Öğrencilerin Mesleğe Yönelik Algıları”. Sosyoloji Araştırmaları Dergisi 18/2 (2015) 108-144.

Kaya N., Turan N. \& Öztürk A. (2011). “Türkiye'de Erkek Hemşire İmgesi”. Uluslararası İnsan Bilimleri Dergisi 8/1 (2011) 16-30.

Khunou G., Pillay R. \& Nethononda A. (2012). 'Social Work is 'Women's Work': An Analysis of Social Work Students' Perceptions of Gender as a Career Choice Determinant”. The Social Work PractitionerResearcher 24/1 (2012) 120-135.

Knight L W. (2014). Jane Addams:Eylemci Bir Ruh. Ankara 2014

Krysik L J. \& Finn J. (2015). Etkili Uygulama İçin Sosyal Hizmet Araştırması. Çev. E. Erbay. Ankara 2015.

Kuş E. (2012). Nicel-Nitel Araştırma Teknikleri. Ankara 2012.

Marshall C. \& Rossman G. B. (2011). Designing Qualitative Research. London 2011.

McPhail B. A. (2004). "Setting the Record Stright: Social Work is not a Female-Dominated Profession". Social Work 49/2 (2004) 323-326.

Moffat K. (2004). "Beyond Male Denial and Female Shame: Learning About Gender in a Sociocultural Concepts Class". Smith College Studies in Social Work 74/2 (2004) 243-256.

Neuman W. L. (2006) Toplumsal Araştırma Yöntemleri. İstanbul 2006.

Öztürk A. B. (2014). Erkeklik ve Kadına Yönelik Aile İçi Şiddet: Eşine Şiddet Uygulayan Erkekler. Doktora Tezi. Hacettepe Üniveristesi, Ankara 2014.

Patton M. Q. (2014). Nitel Araştırma ve Değerlendirme Yöntemleri. Ankara 2014.

Pease B. (2011). "Men in Social Work: Challenging or Reproducing un Unusual Gender Regime". Affilia: Journal of Women and Social Work 26/4 (2011) 406-418. doi: 10.1177/088610991142428207. 
Salsberg E., Quigley L., Mehfoud N., Acquaviva K., Wyche K. \& Sliwa S. (2017). Profile of the Social Work Workforce. USA 2017.

Sancar S. (2009). Erkeklik: İmkansız İktidar. İstanbul 2009.

Selek P. (2008). Sürüne Sürüne Erkek Olmak. İstanbul 2008

Sheafer B. W. \& Horejsi C. J. (2014). Sosyal Hizmet Uygulaması-Temel Teknikler ve İlkeler. Çev. D. B. Çiftçi. Ankara 2014.

Teater B. (2015). Sosyal Hizmet Kuram ve Yöntemleri. Çev. A. Karatay. Ankara 2015.

Türkiye'de Sosyal Hizmet Uzmanı Saylları ve İstihdam Açısından Durumları. (2015). http://shuder.org/sosyalhizmet/sh8.html. Erişim Tarihi: 09.09.2019.

Yıldırım A. \& Şimşek H. (2013). Sosyal Bilimlerde Nitel Araştırma Yöntemleri. Ankara 2013.

Yükseköğrenim Program Atlası (2018). Kaynak: https://yokatlas.yok.gov.tr/. Erişim Tarihi: 20.06.2019.

Zastrow C. (2013). Sosyal Hizmete Giriş. Çev. D. B Çiftçi. Ankara 2013. 
